\title{
An Analysis Of The Determinants Of Intra-Industry Trade: The Case Of Spanish Foreign Trade
}

Joaquín Turmo, (Email: turmo@eco.ub.es), Universidad de Barcelona, Spain Hugo M. Hervitz, (Email: hervitz@hotmail.com), Tecnológico de Monterrey, Spain Carlos Moslares, (Email: moslares@iqs.es), Universitat Ramon Llull, Spain

\begin{abstract}
This paper analyzes the patterns of intra-industry trade observed in Spanish foreign trade and assesses the merits of alternative hypotheses in explaining the determinants of such trade. The results of the econometric analysis support the predictions of the theoretical models. These results show that Spanish intra-industry trade is positively correlated with per capita income, the size of the economies, the existence of a common border and EU membership, while it is negatively correlated with distance and differences in per capita income.
\end{abstract}

\section{INTRODUCTION}

ntra-industry trade (IIT), defined as the simultaneous export and import of products of the same industrial classification, is a phenomenon which has been the subject of significant interest in recent decades, and which has triggered the publication of numerous studies aimed at explaining the main determining factors of this pattern of trade.

The trade theories developed by Ricardo and Hecksher-Ohlin-Samuelson, based on comparative advantage and factor endowment, predict a certain pattern of intra-industry trade. They also predict that opportunities for trade will increase, the larger the differences in productivity, in factor endowments and in demand, between the trading countries. According to these theories, international trade will flourish between countries with unequal economic characteristics, which implies that economic integration schemes among economies that are largely similar is to be discouraged due to the lack of complimentarity in their comparative advantage.

However, the empirical record shows the very opposite. In the European Union, trade among member countries has increased dramatically as soon as they joined the EU, including a high degree of intra-industry trade. This increase in trade among countries with similar economic characteristics, suggested that the increase in IIT was more than a mere statistical curiosity, and resulted in a copious literature aimed at providing possible explanations.

Balassa (1966) highlighted the importance of adjustment costs in situations involving a process of economic integration. Indeed, in such cases it is common to observe adjustment costs resulting from the changes in comparative advantage. Balassa hypothesized that the importance of these costs depends on the level of development of the countries and on the similarities between their economies. In fact, Balassa suggested that intraindustry trade is itself an indicator of such similarities. In sum, his conclusion is that the higher the level of economic development of the trading countries the higher the prevalence of IIT, and this corresponds to lower adjustment costs due to the economic integration process. Thus, he concluded that the importance of adjustment costs in integration schemes had been overstated.

Various trade theories developed in the last three decades attempted to provide explanations for the observed patterns of IIT. In these cases, the emphasis is placed on the characteristics of the different productive sectors and the structure of markets. So, using models that assume production functions exhibiting economies of 
scale and product differentiation (Dixit and Norman, 1980; Helpman and Krugman, 1985), IIT is explained in terms of the differences in market size and the technical possibilities to exploit economies of scale.

An alternative approach is pursued by models of oligopoly and homogeneous products in which the limited size of the local market results in the opening to foreign trade and the reciprocal practice of dumping, which can explain IIT in cases of undifferentiated products (see for example Brander, 1981).

Finally, some newer theories of economic growth (Grossman and Helpman, 1990) help provide a plausible explanation for IIT. The existence of comparative advantage in innovation in a country leads to an increase in product differentiation in the country's industries and to intra-industrial specialization resulting in the export of vertically differentiated products.

The purpose of this paper is the analysis of IIT in Spain, based on the trade links of Spain with 75 countries (see appendix), and the identification of the main factors determining IIT. Section 2 presents the way in which IIT is measured as well as a description of the sources of data. Section 3 presents an overview of the evolution of Spanish foreign trade in the last few decades. Section 4 introduces the proposed dependent and explanatory variables as well as the statistical methodology. Section 5 presents the numerical results of the econometric models and section 6 summarizes the main findings.

\section{THE MEASUREMENT OF INTRA-INDUSTRY TRADE}

Intra-industry trade can be measured using the index developed by Grubel and Lloyd (1975). In its simplest form, for a single industrial sector, the index can be expressed as follows:

$$
I I T_{i j}=1-\frac{\left|X_{i j}-M_{i j}\right|}{\left(X_{i j}+M_{i j}\right)}
$$

where Xij represents the exports of sector $\mathrm{i}$ to country $\mathrm{j}$ and $\mathrm{M}_{\mathrm{ij}}$ the imports of sector $\mathrm{i}$ from country $\mathrm{j}$. follows:

The corresponding aggregate index, measuring IIT for the whole economy of a country is expressed as

$$
I I T_{j}=\frac{\sum_{i=1}^{n}\left(X_{i j}+M_{i j}\right)-\sum_{i=1}^{n}\left|X_{i j}-M_{i j}\right|}{\sum_{i=1}^{n}\left(X_{i j}+M_{i j}\right)}
$$

where $\mathrm{n}$ is the number of industries at a chosen level of aggregation.

It must be noted, however, following Grubel and Lloyd (1975), that this aggregate index is a downwardbiased measure of IIT in countries showing an imbalance in commodity trade. Grubel and Lloyd (1975) proposed an adjusted index that takes into account overall trade imbalance:

$$
I I T_{j}^{a}=\frac{\sum_{i=1}^{n}\left(X_{i j}+M_{i j}\right)-\sum_{i=1}^{n}\left|X_{i j}-M_{i j}\right|}{\sum_{i=1}^{n}\left(X_{i j}+M_{i j}\right)-\left|\sum_{i=1}^{n} X_{i j}-\sum_{i=1}^{n} M_{i j}\right|}
$$


The study of intra-industry trade has an eminently empirical nature and its measurement depends a great deal on the level of disaggregation of the data. Even though in theory each industry is defined on the basis of similarities in factor intensity, official trade statistics are not grouped by industry but by product categories, that offer more disaggregation than industries would. The internationally accepted standard for industrial categories is NACE (National Classification of Economic Activity), but in international trade a different standard is used: CUCI, Uniform Classification for International Trade. This study is based on 4-digit CUCI data.

\section{SPANISH FOREIGN TRADE}

In the 1990's, over 75\% of Spanish foreign trade was made up of manufactured goods, which makes it possible to classify Spain as a developed economy with a level of industrialization appropriate for a OECD member country.

The most crucial landmark for Spanish trade in recent decades has been its joining the European Union in 1986, which constituted an important step towards trade liberalization in two main respects. First, it meant the elimination of tariffs towards other EU members with the corresponding boost in trade within the EU. Secondly, it meant the adoption by Spain of the EU's common external tariff system (TARIC) which implied an across-theboard lowering of Spanish tariffs towards non-EU countries.

This process of trade liberalization resulted in a drastic increase in the openness of the Spanish economy, which had been very closed for decades. The major increases in trade took place with other developed economies, especially within the EU. Table 1 shows the dramatic pace at which the Spanish economy increased its openness in a relatively short period of time.

\begin{tabular}{|l|l|c|c|c|c|}
\hline \multicolumn{7}{|c||}{ TABLE 1: Degree of Openness of the Spanish Economy (\%) } \\
\hline & 1970 & 1980 & 1990 & 1995 & 1997 \\
\hline (X+M)/GDP & 18.2 & 25.1 & 28.5 & 36.6 & 42.7 \\
\hline Source: Banco de España and Dirección General de Aduanas. \\
\hline
\end{tabular}

Table 2 shows that the increased in trade has been asymmetrical, emphasizing OECD countries in general and EU countries in particular. This was to be expected as a result of the integration process and would carry with it the expectation of an increase in IIT over the same period (Pareja and Turmo, 2002).

\begin{tabular}{|l|c|c|c|c|c|c|c|c||}
\hline \multicolumn{8}{|c|}{ TABLE 2: Geographic Composition of Spanish foreign trade (\%) } \\
\hline \multirow{2}{*}{ Region } & \multicolumn{2}{|c|}{1980} & \multicolumn{2}{c|}{$\mathbf{1 9 9 0}$} & \multicolumn{2}{c|}{$\mathbf{1 9 9 5}$} & \multicolumn{2}{c|}{1997} \\
\cline { 2 - 10 } & Import & Export & Import & Export & Import & Export & Import & Export \\
\hline OECD & 48.9 & 59.3 & 76.9 & 83.3 & 76.7 & 81.1 & 75.8 & 80.2 \\
\hline EU & 28.2 & 45.6 & 60.0 & 71.5 & 63.4 & 71.7 & 63.3 & 70.5 \\
\hline OPEC & 29.0 & 14.7 & 6.9 & 3.4 & 5.3 & 2.9 & 6.4 & 2.7 \\
\hline $\begin{array}{l}\text { Other Latin } \\
\text { America }\end{array}$ & 9.3 & 7.8 & 2.7 & 2.6 & 3.1 & 4.8 & 3.1 & 5.2 \\
\hline Other World & 12.8 & 18.2 & 13.4 & 10.7 & 14.8 & 11.2 & 14.7 & 11.9 \\
\hline Source: Banco de España and Dirección General de Aduanas. \\
\hline
\end{tabular}

With respect to the composition of exports and imports by product categories, Table 3 shows that a sharp increase in the importance of durable consumer goods, capital goods, and intermediate industrial goods. Between 
1980 and 1997 the combined weight of these three categories increased from $43.5 \%$ to $72.7 \%$ for imports, and from $69.3 \%$ to $74.1 \%$ for exports.

\begin{tabular}{|c|c|c|c|c|c|c|c|c|}
\hline & \multicolumn{7}{|c|}{ TABLE 3: Structure of Spanish foreign trade by type of goods (\%) } & \\
\hline & $\operatorname{Imp}$ & Exp & $\operatorname{Imp}$ & Exp & Imp & Exp & $\operatorname{Imp}$ & $\operatorname{Exp}$ \\
\hline Consumer goods & 9.6 & 33.9 & 21.0 & 38.5 & 24.1 & 42.0 & 24.4 & 39.8 \\
\hline Durable consumer goods & 3.3 & 10.2 & 8.9 & 17.2 & 8.5 & 20.9 & 9.3 & 18.4 \\
\hline Capital goods & 9.0 & 12.3 & 21.3 & 13.5 & 15.9 & 12.6 & 17.1 & 14.6 \\
\hline Intermediate goods & 81.3 & 53.9 & 57.6 & 47.9 & 60.1 & 45.4 & 58.4 & 45.6 \\
\hline Industrial intermediate goods & 31.2 & 46.8 & 43.2 & 41.2 & 47.6 & 41.8 & 46.3 & 41.1 \\
\hline
\end{tabular}

The increase in the importance of manufactured goods, coupled with the drop in the weight of primary commodities, and the greater degree of openness of the Spanish economy explains the intensification of IIT with the rest of the world.

\section{DETERMINANTS OF INTRA-INDUSTRY TRADE}

When analyzing the determining factors for IIT, the leading theories focus on characteristics of supply and demand by industrial sector (Bergstrand, 1990), as well as characteristics of supply and demand specific to one or more countries (Martin and Orts, 1995; Hu and Ma, 1999).

The studies that focus on industries have identified, on the supply side, the importance of economies of scale and product differentiation, which induce firms and countries to search for foreign markets. Thus, an important explanatory factor for IIT could be the level of technological development of the industry, i.e. the ability to be innovative both in terms of products and processes, increasing efficiency and product differentiation. On the demand side, the focus lies on the analysis of the similarities in consumer behavior across countries, which leads to an increase in IIT.

However, the emphasis of this paper lies on the factors determining IIT at the level of each country. In this respect, it is important to note that IIT is a phenomenon which contradicts the classical concept of comparative advantage, since the latter is based on differences between countries (either in productivity or factor costs) while the former occurs as a result of similarities in the same variables. Thus, IIT will be affected by those factors lying behind these cross-country similarities: factor endowments and technological capability on the supply side, and purchasing power and consumer tastes on the demand side. These factors are closely correlated with the level of economic development of the country; the higher the endowment of human capital and technology, the higher the level of productivity, production capacity and product differentiation; the higher the level of per capita income, the higher the purchasing power of consumers and the preference for wider choice in consumption, be it from domestic or foreign sources.

Since the industrialized economies have a larger diversification in both supply and demand, we expect them to have a larger rate of IIT. Furthermore, we expect the rate of IIT in bilateral trade to be larger, the smaller the differences in per-capita income.

Market size is considered an important factor for IIT, since the larger the demand the better the ability to exploit economies of scale. A country's trade policy is also an important factor for IIT. We expect the rate of IIT to increase for countries involved in trade liberalization and in economic integration schemes, such as the European Union. Finally, geographical proximity is likely to increase IIT, due to lower transportation costs and common borders which may enable the existence of joint industrial zones. 
The econometric model developed in this study attempts to identify the main explanatory variables influencing IIT. The method utilized is Ordinary Least Squares (OLS). The dependent variable utilized is the adjusted IIT index proposed by Grubel and Lloyd (1975). The index ranges from 0 to 100. According to Greenway and Milner (1984) and Balassa (1986), in this case OLS estimation is valid without the need for any transformation of the dependent variable.

The selection of the explanatory variables was done on the basis of the theoretical considerations discussed above, as well as the findings of previous studies (Ekanayake, 2001; Hu and Ma, 1999; Montaner and Orts, 1995). The following variables were included:

- $\quad$ PCGDP (per capita GDP of the trade partner, based on purchasing power parity exchange rates)

$>$ proxy for level of economic development of the trade partner

$>$ expected sign: positive; the greater the level of economic development the larger the expected rate of IIT

- $\quad$ DPCGDP (difference in the levels of PCGDP)

$>$ proxy for the differences in the level of economic development of the two trading partners

$>$ expected sign: negative; the smaller the differences in the level of economic development the larger the expected rate of IIT, due to similar factor endowments and demand characteristics

- GDP (gross domestic product)

$>$ proxy for market size of the trade partner

$>$ expected sign: positive; the greater the market size of the trading partner the larger the expected rate of IIT

- $\quad$ DGDP (difference in the levels of GDP)

$>$ proxy for the differences in the market size of the two trading partners

$>$ expected sign: negative; the smaller the differences in the size of the two markets, the larger the degree of similarity of the two economies and the larger the expected rate of IIT

- $\quad \mathrm{EU}$ (membership in the European Union)

$>$ dummy variable measuring membership in an economic integration scheme

$>$ expected sign: positive; trade among member countries is expected to show a higher rate of ITT

- DIST (distance between the capitals of the two countries)

$>$ proxy for transportation costs

$>$ expected sign: negative; higher transportation costs discourage ITT

- BOR (existence of a common border)

$>$ dummy variable used as a proxy for geographical proximity

$>$ expected sign: positive; the rate of ITT is expected to be higher for neighboring countries

- LAN (existence of a common language)

$>$ dummy variable used as a proxy for cultural affinity

$>$ expected sign: positive; the rate of ITT is expected to be higher for countries with common cultural traditions 
Thus, the regression equation is:

$$
\mathrm{IIT}=\beta_{0}+\beta_{1} \mathrm{GDP}+\beta_{2} \mathrm{DGDP}+\beta_{3} \mathrm{PCGDP}+\beta_{4} \mathrm{DPCGDP}+\beta_{5} \mathrm{EU}+\beta_{6} \mathrm{DIST}+\beta_{7} \mathrm{BOR}+\beta_{8} \mathrm{LAN}+\varepsilon
$$

\section{REGRESSION RESULTS}

Table 4 show the results of the regression for equation 1, utilizing OLS estimators. A second regression, equation 2, was performed, excluding the variables DGDP and LAN.

The results for equation 1 were unsatisfactory since there was evidence of multicollinearity among several variables. The elimination of the two variables DGDP and LAN resulted in a marked increase in the explanatory power and significance of the other variables, while maintaining a respectable $R^{2}$ of 0.70 .

\begin{tabular}{|c|c|c|}
\hline \multicolumn{3}{|c|}{ TABLE 4 } \\
\hline \multirow{2}{*}{ Variable } & $\frac{\text { Value in equation 1 }}{(\mathrm{t}-\text { statistic })}$ & $\frac{\text { Value in equation 2 }}{(\mathrm{t}-\text { statistic) }}$ \\
\hline \multirow{2}{*}{ Constant } & 21.605 & 16.911 \\
& $(4.106)$ & $(3.686)$ \\
\hline \multirow{2}{*}{ GDP } & $3.72 \times 10^{-14}$ & $5.45 \times 10^{-14}$ \\
& $(1.678)$ & $(2.701)$ \\
\hline \multirow{2}{*}{ DGDP } & -4.897 & \\
\hline \multirow{2}{*}{ PCGDP } & $(0.851)$ & 0.00058 \\
& 0.000396 & $(2.560)$ \\
\hline \multirow{2}{*}{ DPCGDP } & $(1.620)$ & $(2.364)$ \\
\hline \multirow{2}{*}{ DIST } & -17.536 & -0.00082 \\
& $(1.986)$ & $(2.363)$ \\
\hline \multirow{2}{*}{ EU } & -0.000623 & $(3.772$ \\
& $(1.675)$ & 15.478 \\
\hline \multirow{2}{*}{ BOR } & 16.417 & $(2.528)$ \\
\hline \multirow{2}{*}{ LAN } & $(3.745)$ & \\
\hline \multirow{2}{*}{} & 15.250 & $\mathrm{R}^{2}=0.700$ \\
\hline
\end{tabular}

Overall, the empirical findings based on equation 2 support the a priori expectations based on the theories analyzed. Both economic and geographical factors were found to be significant in explaining intra-industry trade in Spain. All the estimated parameters had the expected sign. Spanish IIT was found to be more prevalent when trading with countries with similar levels of development (low DPCGDP), when trading with countries with large and rich markets (high GDP and PCGDP), when trading with other members of the EU (EU = 1), and when trading with nearby countries (low DIS and BOR $=1$ ).

\section{CONCLUSIONS}

The foreign trade of Spain is oriented primarily towards the EU, and its high rate of intra-industry trade with other industrialized countries indicates a high degree of economic and commercial integration. In this paper we have attempted to identify the importance of several independent variables in explaining IIT, based on the theoretical writings on this issue. We have focused on three types of factors: those related to the level of economic 
development and the convergence of the economic structure of mature economies, those related to "commercial proximity" through membership in an integration scheme, and those related to geographical proximity.

In all cases the observed pattern was in line with the theoretical expectations. Thus, we can conclude that in the case of Spain intra-industry trade has been positively influenced by the level of development of its trade partners, by their market size and by the convergence of their development levels and economic structure.

Furthermore, the results highlight the importance of membership in the EU for Spanish trade patterns in general and for its IIT in particular. Likewise, we observe a high sensitivity to distance, which stands as a proxy for transport costs.

From the point of view of trade policy, these findings indicate that Spanish foreign trade is perhaps excessively dependent on its immediate vicinity, which suggests that its competitiveness may rely excessively on cost advantages, as opposed to the technological capacity for product differentiation.

\section{REFERENCES}

1. Aquino, A. (1978), "Intra-Industry Trade and Intra-Industry Specialisation as Concurrent Sources of International Trade in Manufactures", Weltwirtschaftliches Archiv, 114, 258-76.

2. Balassa, B. (1966), "Tariff Reductions and Trade in Manufactures among the Industrial Countries", American Economic Review, 56, 466-73.

3. Balassa, B. (1986), "Intra-Industry Specialization: A Cross-Country Analysis", European Economic Review, 30(1), 27-42.

4. Bergstrand, J.H. (1990), "The Heckscher-Ohlin-Samuelson Model, the Linder Hypothesis and the Determinants of Bilateral Intra-Industry Trade", The Economic Journal, 100, 1216-1229.

5. Brander, J.A. (1981), "Intra-Industry Trade in Identical Commodities", Journal of International Economics, 11, 1-14.

6. Dixit, A. K. and V. Norman (1980), Theory of International Trade, Cambridge: Cambridge University Press.

7. Eakanayake, E. (2001), "Determinants of Intra-Industry Trade: The Case of Mexico", The International Trade Journal, Vol. 15 n. 1, 89-112.

8. Grossman, G. and E. Helpman (1990), “Comparative Advantage and Long-Run Growth”, American Economic Review; 80, 796-815.

9. Greenaway, D. and J. Torstensson (1997), "Back to the Future: Taking Stock on Intra-Industry Trade", Weltwirtschaftliches Archiv, vol. 133 (4).

10. Grubel, H.G. and P.J. Lloyd (1975), Intra-Industry Trade. London: Macmillan.

11. Helpman, E. and P. Krugman (1985), Market Structure and Foreign Trade: Increasing Retunes, Imperfect Competition and International Economy, Cambridge, MA: MIT Press.

12. Hu, X. and Y. Ma (1999), "International Intra-Industry Trade of China", Weltwirtschaftliches Archiv, vol. 135 (1), 82-101.

13. Lloyd, P. (1994), “Aggregation by Industry in High-Dimensional Models”, Review of International Economics, 2 (2), 97-111.

14. Martínez Zarzoso, I. (2003), "Relaciones comerciales Unión Europea-Países Socios del Mediterráneo", Boletín Económico de ICE, 2757, Feb. 2003, 23-32.

15. Montaner, J.M. and V. Orts (1995), "Comercio intra-industrial en España: determinantes nacionales y sectoriales", Revista de Economía Aplicada,7: III, 45-62.

16. Pareja, M. and J. Turmo (2002), "Convergencia de la estructura productiva y comercial en la UEM: una aproximación al caso español”, Información Comercial Española, 802, 141-157.

17. Sleuwaegen, L. and K. De Backer (2001), "Multinational Firms, Market Integration and Trade Structure: What Remains of the Standard-Goods Hypothesis?", Weltwirtschaftliches Archiv; 137 (3), 379-403.

18. Torstensson, J. (1999), "Intra-Industry Trade: What does the Theory Predict and How Robust are the Empirical Estimates?”, in M. Brülart and R. Hine (eds.), Intra-Industry Trade and Adjustment: The European Experience, London: Macmillan. 


\begin{tabular}{|c|c|c|c|c|}
\hline \multicolumn{5}{|c|}{ Appendix: Spanish Trade Statistics (1997) } \\
\hline Country & Exports & Imports & IIT Index & $\frac{\text { IIT Adjusted }}{\text { Index }}$ \\
\hline Algeria & $5,592,308$ & $12,395,873$ & 1.223 & 1.288 \\
\hline Angola & 181,991 & 87,098 & 0.018 & 0.021 \\
\hline Argentina & $11,182,786$ & $5,868,117$ & 5.434 & 7.564 \\
\hline Australia & $3,310,270$ & $2,413,126$ & 6.354 & 7.236 \\
\hline Austria & $8,442,499$ & $11,320,501$ & 37.162 & 43.379 \\
\hline Belgium+Luxembourg & $24,433,262$ & $43,916,984$ & 48.267 & 62.498 \\
\hline Bolivia & 218,751 & 123,710 & 1.335 & 2.531 \\
\hline Brazil & $11,348,964$ & $10,087,614$ & 8.817 & 9.276 \\
\hline Bulgaria & 252,720 & $1,244,905$ & 6.986 & 13.292 \\
\hline Cameroon & 25,883 & 322,989 & 0.121 & 0.977 \\
\hline Canada & $4,291,690$ & $3,944,514$ & 3.752 & 17.049 \\
\hline Chile & $5,651,723$ & $2,957,555$ & 3.298 & 4.089 \\
\hline China & $3,834,784$ & $12,748,778$ & 11.694 & 20.206 \\
\hline Colombia & $2,909,911$ & $1,429,415$ & 4.138 & 5.112 \\
\hline Congo & 9,052 & 13,961 & 0.959 & 1.148 \\
\hline Costa Rica & 500,840 & 705,727 & 1.489 & 2.094 \\
\hline Cuba & $4,109,826$ & $1,019,568$ & 2.359 & 5.060 \\
\hline Czech Republic & $4,650,389$ & $2,397,258$ & 28.271 & 40.618 \\
\hline Denmark & $5,963,182$ & $8,469,478$ & 29.290 & 36.199 \\
\hline Dominican Rep. & $1,203,484$ & 110,884 & 1.815 & 8.896 \\
\hline Ecuador & $1,424,963$ & $1,183,413$ & 7.795 & 8.283 \\
\hline Egypt & $2,717,043$ & $1,089,517$ & 11.209 & 22.452 \\
\hline El Salvador & 362,219 & 102,188 & 0.295 & 0.614 \\
\hline Ethiopia & 23,561 & 6,628 & 0.085 & 0.184 \\
\hline Finland & $4,275,599$ & $8,091,268$ & 11.011 & 17.617 \\
\hline France & $164,931,792$ & $195,773,056$ & 55.503 & 60.081 \\
\hline Gambia & 9,002 & 1,922 & 0.000 & 0.000 \\
\hline Germany & $120,687,448$ & $157,045,824$ & 60.989 & 65.388 \\
\hline Ghana & 123,247 & 74,116 & 3.939 & 4.854 \\
\hline Greece & $9,114,924$ & $2,123,354$ & 14.251 & 38.608 \\
\hline Guatemala & 394,185 & 105,196 & 1.283 & 2.764 \\
\hline Guinea & 13,308 & 79,569 & 0.875 & 3.251 \\
\hline Honduras & 213,962 & 223,903 & 2.124 & 2.393 \\
\hline Hong Kong & 808,300 & $1,299,274$ & 15.745 & 28.394 \\
\hline Hungary & $2,736,595$ & $2,924,690$ & 16.324 & 17.157 \\
\hline India & 171,987 & 499,377 & 13.380 & 27.171 \\
\hline Indonesia & 419,627 & 937,179 & 16.133 & 29.454 \\
\hline Ireland & $4,040,832$ & $12,975,846$ & 10.526 & 20.027 \\
\hline Israel & 728,624 & 364,964 & 18.310 & 29.661 \\
\hline
\end{tabular}




\begin{tabular}{|c|c|c|c|c|}
\hline \multicolumn{5}{|c|}{ Appendix: Spanish Trade Statistics (1997) - continued } \\
\hline Country & Exports & Imports & IIT Index & $\frac{\text { IIT Adjusted }}{\text { Index }}$ \\
\hline Italy & $87,941,832$ & $106,914,576$ & 41.787 & 43.503 \\
\hline Ivory Coast & 81,045 & 213,571 & 0.498 & 0.994 \\
\hline Japan & $9,952,166$ & $23,165,524$ & 23.057 & 37.464 \\
\hline Kenya & 42,018 & 16,539 & 1.044 & 1.448 \\
\hline Libya & $1,509,989$ & $7,688,444$ & 0.003 & 0.050 \\
\hline Malaysia & 217,691 & 393,054 & 12.256 & 14.495 \\
\hline Mexico & $8,324,056$ & $8,747,388$ & 2.105 & 3.961 \\
\hline Morocco & $7,309,014$ & $4,587,537$ & 9.727 & 12.335 \\
\hline Netherlands & $37,822,852$ & $51,248,732$ & 37.203 & 40.865 \\
\hline New Zealand & 530,029 & 775,008 & 16.339 & 24.182 \\
\hline Nicaragua & 348,593 & 507,484 & 5.994 & 7.958 \\
\hline Nigeria & 88,219 & $1,144,068$ & 0.000 & 0.003 \\
\hline Norway & $5,028,418$ & $6,507,109$ & 12.732 & 13.561 \\
\hline Pakistan & 81,688 & 171,943 & 0.533 & 0.924 \\
\hline Panama & $1,307,057$ & 238,410 & 2.063 & 2.576 \\
\hline Paraguay & 253,915 & 52,186 & 1.103 & 3.337 \\
\hline Peru & $2,170,133$ & $1,533,366$ & 2.913 & 3.184 \\
\hline Philippines & 107,703 & 98,624 & 15.543 & 17.533 \\
\hline Poland & $8,726,913$ & $2,772,081$ & 12.840 & 37.384 \\
\hline Portugal & $78,879,392$ & $29,140,206$ & 38.500 & 72.592 \\
\hline Romania & 743,438 & 776,929 & 7.333 & 8.441 \\
\hline Senegal & 91,059 & 4,761 & 1.522 & 12.245 \\
\hline Sierra Leone & 3,102 & 24,074 & 0.369 & 1.628 \\
\hline Singapore & 565,939 & 405,457 & 14.408 & 17.241 \\
\hline South Africa & 302,802 & 350,888 & 11.289 & 12.357 \\
\hline South Korea & $4,119,882$ & $8,536,171$ & 12.335 & 21.092 \\
\hline Sweden & $9,007,733$ & $16,051,827$ & 30.036 & 44.202 \\
\hline Switzerland & $10,626,941$ & $14,364,796$ & 27.025 & 39.954 \\
\hline Tanzania & 15,430 & 5,337 & 0.107 & 0.216 \\
\hline Thailand & 613,469 & 570,748 & 6.330 & 6.396 \\
\hline Tunisia & $2,995,357$ & $1,854,948$ & 25.418 & 26.623 \\
\hline Turkey & $11,863,520$ & $4,626,690$ & 14.446 & 21.026 \\
\hline UK & $81,771,608$ & $93,421,224$ & 49.645 & 50.376 \\
\hline Uruguay & $1,378,366$ & 537,554 & 2.432 & 3.481 \\
\hline USA & $40,141,252$ & $55,895,928$ & 9.704 & 26.331 \\
\hline Venezuela & $2,293,496$ & $1,616,364$ & 18.984 & 27.720 \\
\hline
\end{tabular}

Source: World Trade Analyzer and authors' calculations 


\section{NOTES}

